\title{
Comparison of the input photovoltaic water pump with and without floating cooling system
}

\author{
Yusnaini Arifin ${ }^{1 *}$, Muhammad Sarjan ${ }^{1}$, and Aristo Indrajaya ${ }^{1}$ \\ ${ }^{1}$ Electrical Engineering Department, Tadulako University, Palu, Indonesia
}

\begin{abstract}
Solar water pumps are one of the solar technologies that is becoming popular to fulfil the water requirement, particularly in the areas with limited or no access to electricity. However, the voltage of photovoltaic (PV), one of solar technology, drops as the temperature rises. Therefore, efforts are required to lower the temperature in the photovoltaic. This study aimed to observe the effect of cooling PV on direct-coupled water pump, motor and pump connected directly to PV. In this study, the cooling method used is floating method. Two module of PV were used. A photovoltaic module is firmly installed on an artificial pool as a cooling PV and the other without cooling. The results showed that a cooling photovoltaic $(\mathrm{PV})$ produced higher power output transferred to motor and pump and had higher efficiency. In general, the power generated during the period measurement by $\mathrm{PV}$ with cooling is greater than that of $\mathrm{PV}$ without a cooling method. At 17:00 pm, when the intensity reaches $236 \mathrm{~W} / \mathrm{m}^{2}$, the direct-coupled water pump with cooling PV system is able to operate with $9.9484 \mathrm{~W}$ of power input. Meanwhile, under the same intensity, the water pump without cooling PV come into a halt, with $8.6597 \mathrm{~W}$ of the input power.
\end{abstract}

\section{Introduction}

Currently, the world is experiencing an energy crisis, caused by depletion of fossil fuel energy and rapid demand on it [6]. Indonesia is facing energy crisis [4]. Electricity is one of the sectors affected by global energy crisis. Palu is one of the municipalities in Indonesia that suffering from the effect of the electricity crisis. As a result, some villages have no access to electricity. Moreover, the rotating breakdowns are the completion of peak loads, which are greater than the electricity supply of Palu.

Water is also an essential human need. About $98 \%$ of all fresh liquid water presented in the world comes from groundwater [1]. In term of fulfill human need on water, several efforts have been applied, such as hand-dug wells, well accessed via windless and bucket, and finally tube wells with electric conventional water pump. Particularly in the urban area, the use of fossil fuel powered water pump widely used to satisfy water need. However, the need for electric power for water pumps also becomes an obstacle for non-electrified areas, islands, and rural zones. In such area, utilization of undeletable source of energy, such as wind, solar, tide, etc., is required [12]. Usage of solar source, such as photovoltaic, is

*Corresponding author : yusnaini.arifin@gmail.com 
promising to be developed in Indonesia particularly Palu because it is located in tropical regions. Therefore, solar water pump is one of the solar technologies that can meet water need for human without dependence on electricity using diesel fuel, gas, and coal [13].

Solar water pumping based on PV technology converts sunlight into electricity to pump water. The PV panels are connected to a motor (DC or AC). Electrical energy produced by the PV panel converts into mechanical energy produced by the motor which is converted to hydraulic energy by the pump [2]. Directly coupled water pumps system, PV array connected directly to the Direct Current motor and pump, are simple and reliable, but operate in changing power due to intermittent solar radiation [7]. Variation of solar radiation highly affects direct-coupled water pump system operation [14]. The research found that, in the morning and afternoon, when the solar radiation below $300 \mathrm{~W} / \mathrm{m}^{2}$, the water pump systems does not operate.

Performance of a PV water pump mainly depends on the head operation (height of waterfalls), the size of the PV array and the intensity of the radiation. Optimizing pump efficiency, the design should be based on pump characteristics, average efficiency of systems and subsystems, PV array size, and radiation intensity [11]. Two types of pumps commonly used in PV water pumps are volumetric pumps and centrifugal pumps [5]. Furthermore, Solar radiation, the temperature of PV, and energy consumption of pump affect pumped water flow. Voltage changes have more effect on the amount of water pumped than current changes [10].

Electrical output from PV is largely determined by two main factors, namely solar irradiation and temperature $[3,9,15]$. The relationship of PV opened-circuit voltage and temperature PV is directly proposional under the constant solar radiation. Many researches have been conducted to increase the power output and efficiency of PV by cooling method. The cooling method applied is varied, weather passive and active cooling method. The cooling system, a water-cooling sprinkler system, increased the power and efficiency of the polycrystalline PV panel [16]. The PV module connected to a $600 \mathrm{~W}$ grid-tie inverter (model SUN-600G-LCD from Mass power), which provided the alternating current for the house load.

This work aim to evaluate performance of direct-coupled water pump with cooling system. The cooling system applied to this research is floating cooling system, a passive cooling, that does not require energy

\section{Methodology}

This research was conducted in the electrical engineering department at the Tadulako University, in Palu municipality. The setup consists of 2 PV modules that laid in the same orientation. One of PV modules was installed on the artificial pool, floating cooling and the others without cooling.

Temperature of PV modules and ambient temperature was measured using 3 thermocouples. Measurement equipment in measuring electrical data of PV output with and without cooling, such as voltage and current supplied to motor pump, was 3 voltmeters, 2 ampere meters, and 1 pyrometer from Kipp and Zonen. 2 voltmeters were used to measure voltage output of PV modules and the one connected to the pyranometer. Each PV modules was connected directly to the water pum as the load.

Data collection was carried out hourly starting at 09.00 a.m. until 05.00 p.m. The data obtained manually includes the output voltage and the output current of cooling and without cooling PV that transferred to the water pumps. In addition, the performance of water pumps with and without cooling PV in the form of the amount of water produced is obtained. In addition, the performance of water pumps with and without cooling PV in the 
form of the amount of water produced is obtained. The cooling method used is the floating method by making photovoltaic floating on a plastic pool.

The photovoltaic and the water pump specifications used are listed in Table 1 and Table 2, approximately. The PV system with the floating method is shown in Figure 1.

Table 1. Photovoltaic specifications

\begin{tabular}{|c|c|}
\hline Parameters & Description \\
\hline Merk & Kyocera \\
Series number & $1155 \mathrm{XG} 0538$ \\
Technology Type & Polycrystalline \\
Irradiance & $1000 \mathrm{~W} / \mathrm{m}^{2}$ \\
Dimension & $1210 * 808 * 28 \mathrm{~mm}$ \\
Maximum Power Rating, Pm & $87 \mathrm{~W}$ \\
Rated Voltage, Vm & $17,4 \mathrm{~V}$ \\
Rated Current, Im & $5,02 \mathrm{~A}$ \\
Opened circuit Voltage, $\mathrm{V}_{\mathrm{oc}}$ & $21,7 \mathrm{~V}$ \\
Short Circuit Current, $\mathrm{I}_{\mathrm{sc}}$ & $5,34 \mathrm{~A}$ \\
\hline
\end{tabular}

Table 2. Water pump spesifications

\begin{tabular}{|c|c|}
\hline Type & Description \\
\hline Merk & York \\
Model & YRK-BL2512 \\
Voltage & DC-12 V \\
Motor Power & $60 \mathrm{~W} / 5800 \mathrm{rpm}$ \\
Current & $5,4 \mathrm{~A}$ \\
Water Temp & $0^{\circ} \mathrm{C}-60^{\circ} \mathrm{C}$ \\
\hline
\end{tabular}

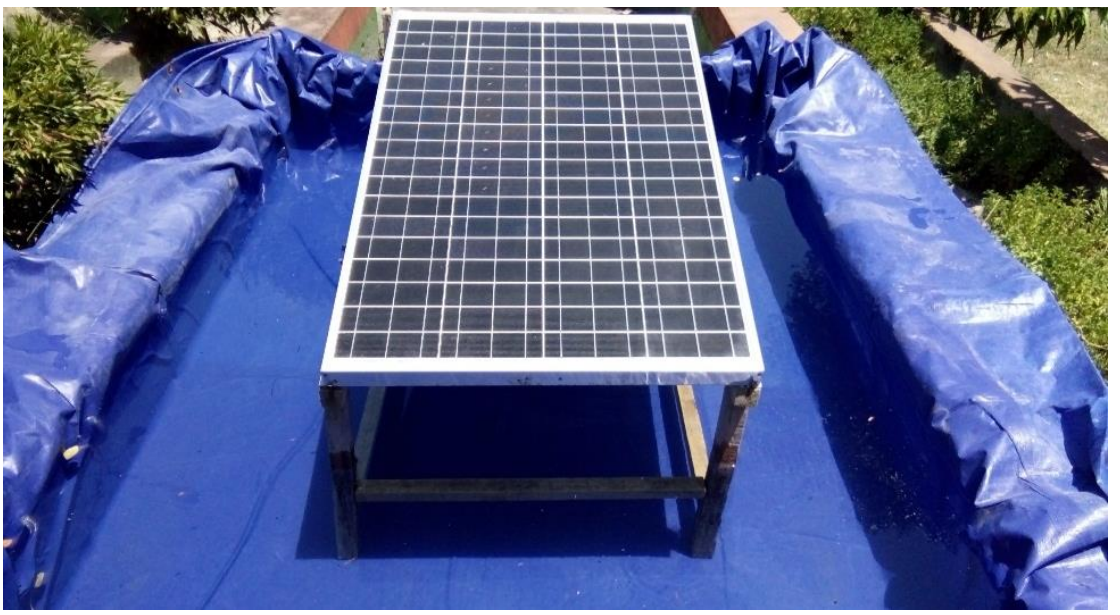

Fig. 1. Installation PV with floating cooling method

\section{Discussion}

Table 3 shows that the cooling system has a significant impact on the direct-coupled pumps. The most significant effect is seen at 05.00 p.m., where, at $236 \mathrm{~W} / \mathrm{m}^{2}$ of intensity, a 
water pump with no cooling system cannot work anymore, while a water pump with a floating cooling can still work.

Table 3. Condition of solar pump in various of sun's intensity.

\begin{tabular}{|c|c|c|c|}
\hline NO. & Period & $\begin{array}{c}\text { Intensity, } \\
\mathbf{E}\left(\mathbf{W} / \mathbf{m}^{\mathbf{2}}\right)\end{array}$ & Condition of pump \\
\hline 2. & 09.00 & 610 & Operate \\
\hline 3. & 10.00 & 831 & Operate \\
\hline 4. & 11.00 & 915 & Operate \\
\hline 5. & 12.00 & 999 & Operate \\
\hline 6. & 13.00 & 1098 & Operate \\
\hline 7. & 14.00 & 686 & Operate \\
\hline 8. & 15.00 & 620 & Operate \\
\hline 9. & 16.00 & 560 & Operate \\
\hline 10. & 17.00 & 236 & Operate (with cooling system), not operate (without cooling \\
& & & system) \\
\hline
\end{tabular}

\subsection{Calculation of Input Power of Photovoltaic}

The following equation (1) is used to calculate the photovoltaic input power:

$$
\operatorname{Pin}=E x A
$$

Where: $\quad$ Pin $=$ Input power of photovoltaic

$E=$ Intensity of sun's radiation

$A=$ Photovoltaic surface area

Based on equation (1), the photovoltaic input power at 09.00 can be calculated as follows:

Pin $=610 \times 0.98=597.8 \mathrm{Watt}$

In the same way, the input power at 10:00 to 17:00 can be seen in table 4 .

\subsection{Calculation of Output Power of Photovoltaic}

The calculation of the photovoltaic output power or the input power of the water pump can be performed with equation (2) as follows:

$$
\text { Pout }=\text { Vm } x \text { Im }
$$

Where: $\quad$ Pout $=$ PV output power or water pump input power

$V m=$ voltage applied to the water pump or output voltage of PV

Im $=$ the current flows in the water pump or output current of PV

From equation (2), the PV power output (water pump input power) at 09.00 can be calculated as follows:

With floating cooling method

Without cooling method

$$
\text { Pout }=7.05 \times 3.82=26.931 \mathrm{Watt}
$$

$$
\text { Pout }=6.69 \times 3.34=22.345 \text { Watt }
$$

Furthermore, in the same way, the calculation of PV output power with and without floating cooling can be seen in Table 4 . 


\subsection{Calculation of photovoltaic efficiency}

PV efficiency is the ratio of PV output power to PV input power. The efficiency of PV can be determined by the following equation (3):

$$
\eta=(\text { Pout } / \text { Pin }) \times 100 \%
$$

Where: $\quad \eta \quad=$ Photovoltaic efficiency

Pout $=$ PV output power or water pump input power

Pin $=$ PV input power

The PV efficiency at 09.00 a.m. can be calculated according to equation (3) as follows:

With floating method

$\eta=(26.931 / 597.8) \times 100 \%=4.5 \%$

Without cooling method

$\eta=(22.345 / 597.8) \times 100 \%=3.74 \%$

Calculation of PV efficiency, with and without cooling, at 10:00 a.m. to 05:00 p.m. can be seen in Table 4.

Table 4. Input, output power and efficiency of PV with and without (wo) cooling system

\begin{tabular}{|c|c|c|c|c|c|c|c|c|c|}
\hline \multirow{2}{*}{ Period } & \multicolumn{2}{|c|}{ Voltage (V) } & \multicolumn{2}{|c|}{ Current (A) } & \multirow{2}{*}{$\begin{array}{c}\text { Input } \\
\text { Power, } \\
\text { Pin } \\
\text { (Watt) }\end{array}$} & \multicolumn{2}{|c|}{$\begin{array}{c}\text { Output power, } \\
\text { Pout (Watt) }\end{array}$} & \multicolumn{2}{|c|}{$\begin{array}{c}\text { Efficiency, } \eta \\
(\%)\end{array}$} \\
\hline & With & wo & With & wo & & With & wo & with & wo \\
\hline 09.00 & 7.05 & 6.69 & 3.82 & 3.34 & 597.8 & 26.931 & 22.345 & 4.5 & 3.73 \\
\hline 10.00 & 10.14 & 9.07 & 4.99 & 4.41 & 814.38 & 50.599 & 39.999 & 6.21 & 4.912 \\
\hline 11.00 & 10.99 & 9.76 & 5.09 & 4.98 & 896.7 & 55.939 & 48.605 & 6.238 & 5.420 \\
\hline 12.00 & 11.96 & 10.99 & 5.11 & 5.01 & 979.02 & 61.116 & 55.060 & 6.243 & 5.624 \\
\hline 13.00 & 12.55 & 11.61 & 5.15 & 5.13 & 1076.04 & 64.633 & 59.559 & 6.007 & 5.535 \\
\hline 14.00 & 8.41 & 7.11 & 4.39 & 3.78 & 672.28 & 36.920 & 26.876 & 5.492 & 3.998 \\
\hline 15.00 & 7.11 & 6.81 & 3.97 & 3.27 & 607.6 & 28.227 & 22.269 & 4.646 & 3.665 \\
\hline 16.00 & 6.57 & 6.36 & 3.31 & 3.06 & 548.8 & 21.747 & 19.462 & 4.483 & 3.546 \\
\hline 17.00 & 6.46 & 6.23 & 1.54 & 1.30 & 231.28 & 9.948 & 8.099 & 4.301 & 3.502 \\
\hline
\end{tabular}

Table 4 shows that the output power of PV with cooling system, entering the pump, is higher than PV without cooling. This is due to a significant increase in voltage. This leads to better performance of the water pump.

\section{Conclusion}

In conclusion, the floating cooling method applied to the PV directly connected water pump improves pump performance. Under highest intensity, $1098 \mathrm{~W} / \mathrm{m}^{2}$ at 01.00 p.m., the output power produced by the cooling PV supplied to the pump was $64.633 \mathrm{~W}$ that is higher than the non-cooling PV. In addition, at the lowest intensity of $236 \mathrm{~W} / \mathrm{m}^{2}$, at $05.00 \mathrm{a} . \mathrm{m}$., the water pump connected to the PV without cooling came into a halt, while the other still operates. Furthermore, direct-coupled water pump with cooling PV is able to improve $8.53 \%$ of PV efficiency under the highest intensity. 


\section{References}

1. Chambel, A. (2015). The role of groundwater in the management of water resources in the World. IAHS-AISH Proceedings and Reports, 366 (June 2014), 107-108. https://doi.org/10.5194/piahs-366-107-2015

2. Chandel, S. S., Nagaraju Naik, M., \& Chandel, R. (2015). Review of solar photovoltaic water pumping system technology for irrigation and community drinking water supplies. Renewable and Sustainable Energy Reviews, 49, 1084-1099. https://doi.org/10.1016/j.rser.2015.04.083

3. Coskun, C., Toygar, U., Sarpdag, O., \& Oktay, Z. (2017). Sensitivity analysis of implicit correlations for photovoltaic module temperature: A review. Journal of Cleaner Production, 164, 1474-1485. https://doi.org/10.1016/j.jclepro.2017.07.080

4. Indonesia in energy crisis: Pertamina director - Business - The Jakarta Post. (n.d.). Retrieved April 9, 2020, from https://www.thejakartapost.com/news/2017/12/07/indonesia-in-energy-crisispertamina-director.html

5. Jagan, M., Rao, M., Sahu, M. K., \& Subudhi, P. K. (2018). ScienceDirect PMME 2016 PV Based Water Pumping System For. Materials Today: Proceedings, 5(1), 10081016. https://doi.org/10.1016/j.matpr.2017.11.177

6. Kornelakis, A. (2010). Multiobjective Particle Swarm Optimization for the optimal design of photovoltaic grid-connected systems. Solar Energy, 84(12), 2022-2033. https://doi.org/10.1016/j.solener.2010.10.001

7. Kou, Q., Klein, S. A., \& Beckman, W. A. (1998). A method for estimating the longterm performance of direct-coupled PV pumping systems. Solar Energy, 64(1-3), 3340. https://doi.org/10.1016/S0038-092X(98)00049-8

8. Kusma, A. (2015). Strategies for Troubleshooting Energy Crisis in Indonesia Through Optimization Electrical Energy. 16-31.

9. Mehmood, U., Al-Ahmed, A., Al-Sulaiman, F. A., Malik, M. I., Shehzad, F., \& Khan, A. U. H. (2017). Effect of temperature on the photovoltaic performance and stability of solid-state dye-sensitized solar cells: A review. Renewable and Sustainable Energy Reviews, 79(May), 946-959. https://doi.org/10.1016/j.rser.2017.05.114

10. Nogueira, C. E. C., Bedin, J., Niedzialkoski, R. K., De Souza, S. N. M., \& Das Neves, J. C. M. (2015). Performance of monocrystalline and polycrystalline solar panels in a water pumping system in Brazil. Renewable and Sustainable Energy Reviews, 51, 1610-1616. https://doi.org/10.1016/j.rser.2015.07.082

11. Odeh, I., Yohanis, Y. G., \& Norton, B. (2006). Influence of pumping head, insolation and PV array size on PV water pumping system performance. Solar Energy, 80(1), 5164. https://doi.org/10.1016/j.solener.2005.07.009

12. Patil, S. S., \& Zende, R. M. (2017). Solar powered water pumping system. Proceedings of 2017 3rd IEEE International Conference on Sensing, Signal Processing and Security, ICSSS 2017, 186-190. https://doi.org/10.1109/SSPS.2017.8071589

13. robert Foster, Majid Ghassemi, Alma CotaEnergy, R. (2009). SOLAR ENERGY Renewable Energy and the Environment (abbas ghassemi (New Mexico State University), Ed.). CRC Press Taylor \& Francis Group.

14. Sarjan, M., Arifin, Y., Amir, A., \& Masarrang, M. (2017). Pompa Air dengan Sumber Photovoltaic. (November), 169-172. 
15. Wu, C. W., Peng, Q., \& Huang, C. G. (2017). Thermal analysis on multijunction photovoltaic cell under oblique incident laser irradiation. Energy, 134, 248-255. https://doi.org/10.1016/j.energy.2017.06.018

16. Zilli, B. M., Lenz, A. M., de Souza, S. N. M., Secco, D., Nogueira, C. E. C., Junior, O. H. A., Gurgacz, F. (2018). Performance and effect of water-cooling on a microgeneration system of photovoltaic solar energy in Paraná Brazil. Journal of Cleaner Production, 192, 477-485. https://doi.org/10.1016/j.jclepro.2018.04.241 
promising to be developed in Indonesia particularly Palu because it is located in tropical regions. Therefore, solar water pump is one of the solar technologies that can meet water need for human without dependence on electricity using diesel fuel, gas, and coal [13].

Solar water pumping based on PV technology converts sunlight into electricity to pump water. The PV panels are connected to a motor (DC or AC). Electrical energy produced by the PV panel converts into mechanical energy produced by the motor which is converted to hydraulic energy by the pump [2]. Directly coupled water pumps system, PV array connected directly to the Direct Current motor and pump, are simple and reliable, but operate in changing power due to intermittent solar radiation [7]. Variation of solar radiation highly affects direct-coupled water pump system operation [14]. The research found that, in the morning and afternoon, when the solar radiation below $300 \mathrm{~W} / \mathrm{m}^{2}$, the water pump systems does not operate.

Performance of a PV water pump mainly depends on the head operation (height of waterfalls), the size of the PV array and the intensity of the radiation. Optimizing pump efficiency, the design should be based on pump characteristics, average efficiency of systems and subsystems, PV array size, and radiation intensity [11]. Two types of pumps commonly used in PV water pumps are volumetric pumps and centrifugal pumps [5]. Furthermore, Solar radiation, the temperature of PV, and energy consumption of pump affect pumped water flow. Voltage changes have more effect on the amount of water pumped than current changes [10].

Electrical output from PV is largely determined by two main factors, namely solar irradiation and temperature $[3,9,15]$. The relationship of PV opened-circuit voltage and temperature PV is directly proposional under the constant solar radiation. Many researches have been conducted to increase the power output and efficiency of PV by cooling method. The cooling method applied is varied, weather passive and active cooling method. The cooling system, a water-cooling sprinkler system, increased the power and efficiency of the polycrystalline PV panel [16]. The PV module connected to a $600 \mathrm{~W}$ grid-tie inverter (model SUN-600G-LCD from Mass power), which provided the alternating current for the house load.

This work aim to evaluate performance of direct-coupled water pump with cooling system. The cooling system applied to this research is floating cooling system, a passive cooling, that does not require energy

\section{Methodology}

This research was conducted in the electrical engineering department at the Tadulako University, in Palu municipality. The setup consists of 2 PV modules that laid in the same orientation. One of PV modules was installed on the artificial pool, floating cooling and the others without cooling.

Temperature of PV modules and ambient temperature was measured using 3 thermocouples. Measurement equipment in measuring electrical data of PV output with and without cooling, such as voltage and current supplied to motor pump, was 3 voltmeters, 2 ampere meters, and 1 pyrometer from Kipp and Zonen. 2 voltmeters were used to measure voltage output of PV modules and the one connected to the pyranometer. Each PV modules was connected directly to the water pum as the load.

Data collection was carried out hourly starting at 09.00 a.m. until 05.00 p.m. The data obtained manually includes the output voltage and the output current of cooling and without cooling PV that transferred to the water pumps. In addition, the performance of water pumps with and without cooling PV in the form of the amount of water produced is obtained. In addition, the performance of water pumps with and without cooling PV in the 
form of the amount of water produced is obtained. The cooling method used is the floating method by making photovoltaic floating on a plastic pool.

The photovoltaic and the water pump specifications used are listed in Table 1 and Table 2, approximately. The PV system with the floating method is shown in Figure 1.

Table 1. Photovoltaic specifications

\begin{tabular}{|c|c|}
\hline Parameters & Description \\
\hline Merk & Kyocera \\
Series number & $1155 \mathrm{XG} 0538$ \\
Technology Type & Polycrystalline \\
Irradiance & $1000 \mathrm{~W} / \mathrm{m}^{2}$ \\
Dimension & $1210 * 808 * 28 \mathrm{~mm}$ \\
Maximum Power Rating, Pm & $87 \mathrm{~W}$ \\
Rated Voltage, Vm & $17,4 \mathrm{~V}$ \\
Rated Current, Im & $5,02 \mathrm{~A}$ \\
Opened circuit Voltage, $\mathrm{V}_{\mathrm{oc}}$ & $21,7 \mathrm{~V}$ \\
Short Circuit Current, $\mathrm{I}_{\mathrm{sc}}$ & $5,34 \mathrm{~A}$ \\
\hline
\end{tabular}

Table 2. Water pump spesifications

\begin{tabular}{|c|c|}
\hline Type & Description \\
\hline Merk & York \\
Model & YRK-BL2512 \\
Voltage & DC-12 V \\
Motor Power & $60 \mathrm{~W} / 5800 \mathrm{rpm}$ \\
Current & $5,4 \mathrm{~A}$ \\
Water Temp & $0^{\circ} \mathrm{C}-60^{\circ} \mathrm{C}$ \\
\hline
\end{tabular}

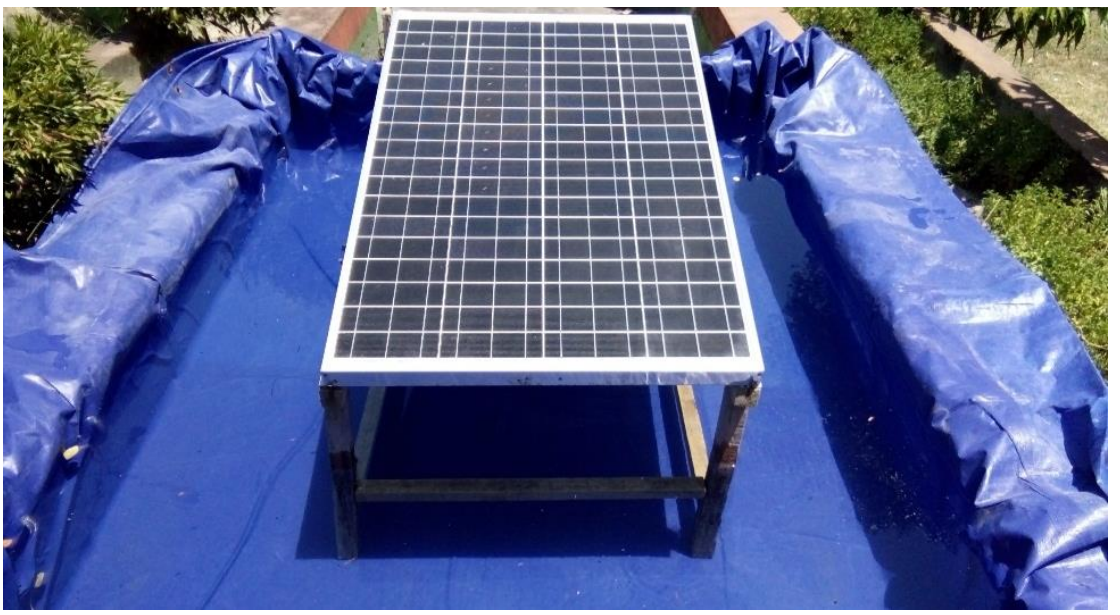

Fig. 1. Installation PV with floating cooling method

\section{Discussion}

Table 3 shows that the cooling system has a significant impact on the direct-coupled pumps. The most significant effect is seen at 05.00 p.m., where, at $236 \mathrm{~W} / \mathrm{m}^{2}$ of intensity, a 
water pump with no cooling system cannot work anymore, while a water pump with a floating cooling can still work.

Table 3. Condition of solar pump in various of sun's intensity.

\begin{tabular}{|c|c|c|c|}
\hline NO. & Period & $\begin{array}{c}\text { Intensity, } \\
\mathbf{E}\left(\mathbf{W} / \mathbf{m}^{\mathbf{2}}\right)\end{array}$ & Condition of pump \\
\hline 2. & 09.00 & 610 & Operate \\
\hline 3. & 10.00 & 831 & Operate \\
\hline 4. & 11.00 & 915 & Operate \\
\hline 5. & 12.00 & 999 & Operate \\
\hline 6. & 13.00 & 1098 & Operate \\
\hline 7. & 14.00 & 686 & Operate \\
\hline 8. & 15.00 & 620 & Operate \\
\hline 9. & 16.00 & 560 & Operate \\
\hline 10. & 17.00 & 236 & Operate (with cooling system), not operate (without cooling \\
& & & system) \\
\hline
\end{tabular}

\subsection{Calculation of Input Power of Photovoltaic}

The following equation (1) is used to calculate the photovoltaic input power:

$$
\operatorname{Pin}=E x A
$$

Where: $\quad$ Pin $=$ Input power of photovoltaic

$E=$ Intensity of sun's radiation

$A=$ Photovoltaic surface area

Based on equation (1), the photovoltaic input power at 09.00 can be calculated as follows:

Pin $=610 \times 0.98=597.8 \mathrm{Watt}$

In the same way, the input power at 10:00 to 17:00 can be seen in table 4 .

\subsection{Calculation of Output Power of Photovoltaic}

The calculation of the photovoltaic output power or the input power of the water pump can be performed with equation (2) as follows:

$$
\text { Pout }=\text { Vm } x \text { Im }
$$

Where: $\quad$ Pout $=$ PV output power or water pump input power

$V m=$ voltage applied to the water pump or output voltage of PV

Im $=$ the current flows in the water pump or output current of PV

From equation (2), the PV power output (water pump input power) at 09.00 can be calculated as follows:

With floating cooling method

Without cooling method

$$
\text { Pout }=7.05 \times 3.82=26.931 \mathrm{Watt}
$$

$$
\text { Pout }=6.69 \times 3.34=22.345 \text { Watt }
$$

Furthermore, in the same way, the calculation of PV output power with and without floating cooling can be seen in Table 4 . 


\subsection{Calculation of photovoltaic efficiency}

PV efficiency is the ratio of PV output power to PV input power. The efficiency of PV can be determined by the following equation (3):

$$
\eta=(\text { Pout } / \text { Pin }) \times 100 \%
$$

Where: $\quad \eta \quad=$ Photovoltaic efficiency

Pout $=$ PV output power or water pump input power

Pin $=$ PV input power

The PV efficiency at 09.00 a.m. can be calculated according to equation (3) as follows:

With floating method

$\eta=(26.931 / 597.8) \times 100 \%=4.5 \%$

Without cooling method

$\eta=(22.345 / 597.8) \times 100 \%=3.74 \%$

Calculation of PV efficiency, with and without cooling, at 10:00 a.m. to 05:00 p.m. can be seen in Table 4.

Table 4. Input, output power and efficiency of PV with and without (wo) cooling system

\begin{tabular}{|c|c|c|c|c|c|c|c|c|c|}
\hline \multirow{2}{*}{ Period } & \multicolumn{2}{|c|}{ Voltage (V) } & \multicolumn{2}{|c|}{ Current (A) } & \multirow{2}{*}{$\begin{array}{c}\text { Input } \\
\text { Power, } \\
\text { Pin } \\
\text { (Watt) }\end{array}$} & \multicolumn{2}{|c|}{$\begin{array}{c}\text { Output power, } \\
\text { Pout (Watt) }\end{array}$} & \multicolumn{2}{|c|}{$\begin{array}{c}\text { Efficiency, } \eta \\
(\%)\end{array}$} \\
\hline & With & wo & With & wo & & With & wo & with & wo \\
\hline 09.00 & 7.05 & 6.69 & 3.82 & 3.34 & 597.8 & 26.931 & 22.345 & 4.5 & 3.73 \\
\hline 10.00 & 10.14 & 9.07 & 4.99 & 4.41 & 814.38 & 50.599 & 39.999 & 6.21 & 4.912 \\
\hline 11.00 & 10.99 & 9.76 & 5.09 & 4.98 & 896.7 & 55.939 & 48.605 & 6.238 & 5.420 \\
\hline 12.00 & 11.96 & 10.99 & 5.11 & 5.01 & 979.02 & 61.116 & 55.060 & 6.243 & 5.624 \\
\hline 13.00 & 12.55 & 11.61 & 5.15 & 5.13 & 1076.04 & 64.633 & 59.559 & 6.007 & 5.535 \\
\hline 14.00 & 8.41 & 7.11 & 4.39 & 3.78 & 672.28 & 36.920 & 26.876 & 5.492 & 3.998 \\
\hline 15.00 & 7.11 & 6.81 & 3.97 & 3.27 & 607.6 & 28.227 & 22.269 & 4.646 & 3.665 \\
\hline 16.00 & 6.57 & 6.36 & 3.31 & 3.06 & 548.8 & 21.747 & 19.462 & 4.483 & 3.546 \\
\hline 17.00 & 6.46 & 6.23 & 1.54 & 1.30 & 231.28 & 9.948 & 8.099 & 4.301 & 3.502 \\
\hline
\end{tabular}

Table 4 shows that the output power of PV with cooling system, entering the pump, is higher than PV without cooling. This is due to a significant increase in voltage. This leads to better performance of the water pump.

\section{Conclusion}

In conclusion, the floating cooling method applied to the PV directly connected water pump improves pump performance. Under highest intensity, $1098 \mathrm{~W} / \mathrm{m}^{2}$ at 01.00 p.m., the output power produced by the cooling PV supplied to the pump was $64.633 \mathrm{~W}$ that is higher than the non-cooling PV. In addition, at the lowest intensity of $236 \mathrm{~W} / \mathrm{m}^{2}$, at $05.00 \mathrm{a} . \mathrm{m}$., the water pump connected to the PV without cooling came into a halt, while the other still operates. Furthermore, direct-coupled water pump with cooling PV is able to improve $8.53 \%$ of PV efficiency under the highest intensity. 


\section{References}

1. Chambel, A. (2015). The role of groundwater in the management of water resources in the World. IAHS-AISH Proceedings and Reports, 366 (June 2014), 107-108. https://doi.org/10.5194/piahs-366-107-2015

2. Chandel, S. S., Nagaraju Naik, M., \& Chandel, R. (2015). Review of solar photovoltaic water pumping system technology for irrigation and community drinking water supplies. Renewable and Sustainable Energy Reviews, 49, 1084-1099. https://doi.org/10.1016/j.rser.2015.04.083

3. Coskun, C., Toygar, U., Sarpdag, O., \& Oktay, Z. (2017). Sensitivity analysis of implicit correlations for photovoltaic module temperature: A review. Journal of Cleaner Production, 164, 1474-1485. https://doi.org/10.1016/j.jclepro.2017.07.080

4. Indonesia in energy crisis: Pertamina director - Business - The Jakarta Post. (n.d.). Retrieved April 9, 2020, from https://www.thejakartapost.com/news/2017/12/07/indonesia-in-energy-crisispertamina-director.html

5. Jagan, M., Rao, M., Sahu, M. K., \& Subudhi, P. K. (2018). ScienceDirect PMME 2016 PV Based Water Pumping System For. Materials Today: Proceedings, 5(1), 10081016. https://doi.org/10.1016/j.matpr.2017.11.177

6. Kornelakis, A. (2010). Multiobjective Particle Swarm Optimization for the optimal design of photovoltaic grid-connected systems. Solar Energy, 84(12), 2022-2033. https://doi.org/10.1016/j.solener.2010.10.001

7. Kou, Q., Klein, S. A., \& Beckman, W. A. (1998). A method for estimating the longterm performance of direct-coupled PV pumping systems. Solar Energy, 64(1-3), 3340. https://doi.org/10.1016/S0038-092X(98)00049-8

8. Kusma, A. (2015). Strategies for Troubleshooting Energy Crisis in Indonesia Through Optimization Electrical Energy. 16-31.

9. Mehmood, U., Al-Ahmed, A., Al-Sulaiman, F. A., Malik, M. I., Shehzad, F., \& Khan, A. U. H. (2017). Effect of temperature on the photovoltaic performance and stability of solid-state dye-sensitized solar cells: A review. Renewable and Sustainable Energy Reviews, 79(May), 946-959. https://doi.org/10.1016/j.rser.2017.05.114

10. Nogueira, C. E. C., Bedin, J., Niedzialkoski, R. K., De Souza, S. N. M., \& Das Neves, J. C. M. (2015). Performance of monocrystalline and polycrystalline solar panels in a water pumping system in Brazil. Renewable and Sustainable Energy Reviews, 51, 1610-1616. https://doi.org/10.1016/j.rser.2015.07.082

11. Odeh, I., Yohanis, Y. G., \& Norton, B. (2006). Influence of pumping head, insolation and PV array size on PV water pumping system performance. Solar Energy, 80(1), 5164. https://doi.org/10.1016/j.solener.2005.07.009

12. Patil, S. S., \& Zende, R. M. (2017). Solar powered water pumping system. Proceedings of 2017 3rd IEEE International Conference on Sensing, Signal Processing and Security, ICSSS 2017, 186-190. https://doi.org/10.1109/SSPS.2017.8071589

13. robert Foster, Majid Ghassemi, Alma CotaEnergy, R. (2009). SOLAR ENERGY Renewable Energy and the Environment (abbas ghassemi (New Mexico State University), Ed.). CRC Press Taylor \& Francis Group.

14. Sarjan, M., Arifin, Y., Amir, A., \& Masarrang, M. (2017). Pompa Air dengan Sumber Photovoltaic. (November), 169-172. 
15. Wu, C. W., Peng, Q., \& Huang, C. G. (2017). Thermal analysis on multijunction photovoltaic cell under oblique incident laser irradiation. Energy, 134, 248-255. https://doi.org/10.1016/j.energy.2017.06.018

16. Zilli, B. M., Lenz, A. M., de Souza, S. N. M., Secco, D., Nogueira, C. E. C., Junior, O. H. A., Gurgacz, F. (2018). Performance and effect of water-cooling on a microgeneration system of photovoltaic solar energy in Paraná Brazil. Journal of Cleaner Production, 192, 477-485. https://doi.org/10.1016/j.jclepro.2018.04.241 